\title{
ケーソン岸壁を対象とした液状化対策範囲の検 討に関する模型振動台試験
}

SHAKING TABLE TESTS ON AREA OF LIQUEFACTION COUNTERMEASURES FOR CAISSON TYPE QUAY WALLS

\author{
山㟝浩之 ${ }^{1}$ 永野賢次 ${ }^{2}$ \\ Hiroyuki YAMAZAKI and Kenji NAGANO \\ 1正会員 工修 港湾空港技術研究所 地盤・構造部（テ239-0826 神奈川県横須賀市長瀬3-1-1） \\ 非会員 同上
}

\begin{abstract}
Soil improvement area as liquefaction countermeasures is determined considering the strength reduction of a portion adjacent to the unimproved area. The strength reduction is caused by the transmission of the excess pore water pressure from the unimproved area to the portion. Therefore, the improvement area is designed widely enough to keep the stability of structures ignoring the strength of the strength reduction area. However, the consideration of the strength reduction may not be necessary if the soil contains many fines, because the permeability is low and the excess pore pressure transmission may be small. In this paper the effect of the permeability of the improved area on its strength reduction is investigated by shaking table tests. The tests are conducted on a caisson type quay wall and the behavior of the backfill and the caisson are investigated. In the tests cellulose solution is used to control the permeability of soil. The test results show the caisson displacement is smaller in the case of low permeable backfill without consideration of the strength reduction area than in the case of high permeable backfill with consideration of the strength reduction area. However, the pore pressure behavior does not clearly show the difference.
\end{abstract}

Key Words : Liquefaction, Countermeasures, Caisson type quay wall, Fines, Permeability Improved area

\section{1.はじめに}

岸壁背後地盤を対象とした液状化対策範囲の設定 法が提案されており ${ }^{1)}$, これは, 細粒分を多く含ま ない，いわゆるきれいな砂を対象に振動台試験など に基づき提案されたものである。しかしながら，近 年, 細粒分を多く含む砂地盤に対しても液状化対策 を講じるケースが増えている。このような細粒分を 多く含む砂地盤に対して同設定法が適用される場合 には次のような課題があると思われる.
同設定法においては，液状化する地盤（無対策地 盤）から対策地盤に対して伝播する過剩間隙水圧の 影響（いわゆる2 次液状化）を考慮するための余裕 域が図-1の $30^{\circ}$ の範囲で示すように設けられ，ケー ソンの安定性が検討される。 また，上層部の非液状 化層も過剩間隙水圧の伝播により液状化すると考え ている。細粒分が多い場合には透水係数が小さいの で，きれいな砂のように震動中には過剩間隙水圧の 伝播は起こりにくいと考えられ，対策範囲の設定に おいて余裕域の考慮は必要でない可能性がある。

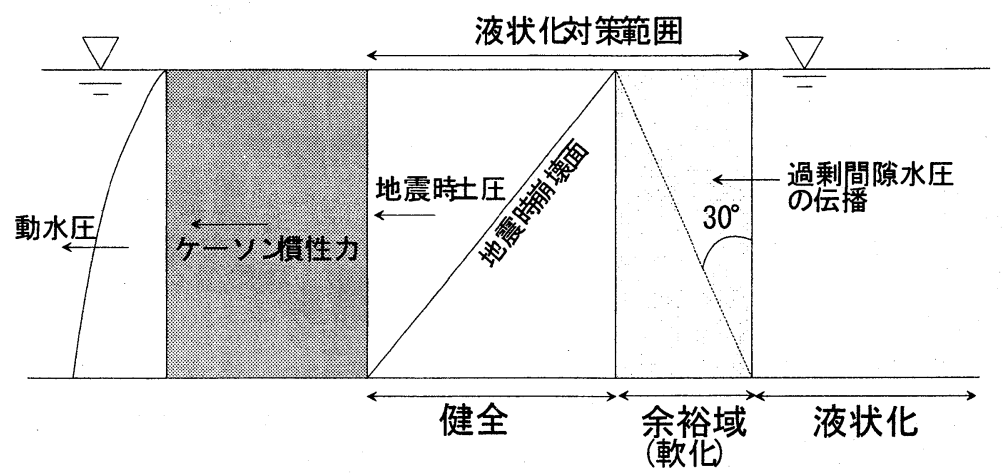

図-1 現行の液状化対策範囲の設定の模式図 
本報告は，ケーソン岸壁を対象とした模型振動台 試験を行い，このような対策範囲に関する課題につ いて基礎的検討を行うことを目的としている.

\section{2. 振動台試験概要}

振動台試験は細粒分を多く含む地盤と細粒分を含 まないきれいな砂地盤の 2 種類について行い，両者 の比較を目的に行った．ただし，細粒分を多く含む 地盤の作成は困難であり，また細粒分の混入により 粒度特性が異なり液状化強度などの力学特性自体が 異なったものとなる．そこで，ここでは2次液状化 の大きな要因となる透水性に着目することとして， セルロース水溶液を間隙水に用いて細粒分を多く含 む地盤とした。

以下に実験の概要を示す.

\section{（1）振動箱・模型ヶーソン・模型地盤・試験ヶー} ス

\section{a）振動箱}

図-2に示すように余裕域に関する振動台試験を 行った. 振動箱は長さ $85 \mathrm{~cm}$, 高さ $60 \mathrm{~cm}$, 奥行き $36 \mathrm{~cm}$ あり，その中に模型ケーソン，模型地盤を各々設置 作成した。

b) 模型ヶーソン

模型ケーソンは，計測用 1 個とダミー函 2 個の計 3 個用意して法線方向に並べ，中央に計測用を置いて 計測を行った。両端のダミーは振動箱側面との摩擦 の影響を除くためのものである。模型ケーソンの単 位体積重量は $\gamma_{\mathrm{ct}}=19.8 \mathrm{kN} / \mathrm{m}^{3}$ である.

\section{c）模型地盤}

模型地盤は砕石を用いた基盤層を層厚 $15 \mathrm{~cm}$ で作成 し, その上に相馬 6 号砂を用いて十分締固めた基礎 地盤を設けた。基礎地盤の上に，前述したケーソン を設置し，その背後に基礎地盤と同じ相馬 6 号砂を 用いて裏埋めを作成した。相馬6号砂の物理特性お よび水道水，セルロース水溶液を用いた場合の相馬 6号砂の透水係数を表-1に示す.

表-1 相馬6号砂の物性値

\begin{tabular}{|c|c|}
\hline \multicolumn{3}{|c|}{ 試料名: 相馬 6 号砂 } \\
\hline 土粒子密度: $\rho_{s}\left(\mathrm{~g} / \mathrm{cm}^{3}\right)$ & 2.647 \\
\hline 最小間隙比: $\mathrm{e}_{\min }$ & 0.664 \\
\hline 最大間隙比: $\mathrm{e}_{\max }$ & 1.121 \\
\hline 均等係数: $U_{\mathrm{c}}$ & 2.31 \\
\hline 中央粒径 $\left.\mathrm{d}_{50} \mathrm{~cm}\right)$ & 0.06 \\
\hline 透水係数: 水 $(\mathrm{cm} / \mathrm{s})$ & $0.9 \times 10^{-2}$ \\
\hline 透水係数: セルロ一ス水溶液 $(\mathrm{cm} / \mathrm{s})$ & $0.6 \times 10^{-4}$ \\
\hline
\end{tabular}

裏埋めは，A地盤，B地盤，C地盤からなっている. A地盤は, 図-1で示した地震時崩壊面から定まる液 状化対策範囲で，設計で想定された地震時土圧に対 してケーソンが抵抗するために確保されなければな らない範囲である。B地盤は余裕域でここでの検討
の対象となり，実験ではB地盤を改良した場合と改 良しない場合について比較している。余裕域は現行 設計法では，図-1で示したように $30^{\circ}$ の範囲で定ま る.C地盤は無改良域に相当するものである.A地盤， B地盤の地盤改良は締固めで行っている。無改良域 の相対密度はDr $\fallingdotseq 15 \%\left(\gamma^{\prime}=7.87 \mathrm{kN} / \mathrm{m}^{2}\right)$ ，改良域はDr $\fallingdotseq 80 \%\left(\gamma^{\prime}=9.19 \mathrm{kN} / \mathrm{m}^{2}\right)$ である。

地下水位は，条件を簡単にするためにケーソン前 面の水位をケーソン天端と同じ位置として，地下水 位が地表面と一致するようにした。

地盤の透水係数については，表-1に示したように， 水を用いたものは $\mathrm{k}=0.9 \times 10^{-2} \mathrm{~cm} / \mathrm{s}$ ，セルロース水溶 液を用いたものは $=0.6 \times 10^{-4} \mathrm{~cm} / \mathrm{s}$ と両者で 2 オー ダーの違いがある。

\section{d）試験ケース}

模型実験はケーソン背後の裏埋めを，余裕域を改 良した場合と改良しない場合について，間隙を水道 水とした場合とセルロース水溶液とした場合の計 4 ケース行った。

表-2 試験ケース

\begin{tabular}{|c|c|c|c|c|}
\hline ケース番号 & \multicolumn{3}{|c|}{ 地盤条件(相対密度\%) } & 間䏚 \\
\hline & & B地盤:余裕 & C地盤 & \\
\hline$\frac{1}{T-x}$ & 改良(80) & 改良 (80) & 未改良 (15) & 水 \\
\hline T-ス36 & 改良(80) & 未改良 (15) & 未改良(15) & 水 \\
\hline T-ス40 & 改良 (80) & 改良 (80) & 末改良(15) & セルロース水溶液 \\
\hline ケース 45 & 改良 (80) & 未改良(15) & 未改良 (15) & セルロース水 \\
\hline
\end{tabular}

\section{（2）加振と計測}

加振は水平一方向に正弦波で加速度振幅を 50 ,

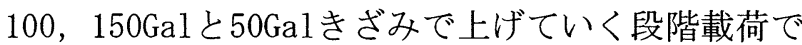
行った. 各載荷段階での加振振動数は $20 \mathrm{~Hz}$, 回数は 20 回で，加振時間は 1 秒である.

図-2のように加速度計と間隙水圧計を地盤に設置 し，加振中の加速度と間隙水圧を計測している。間 隙水圧計はA〜Cの各地盤内の左右に設置している. 模型ケーソンにはレーザー变位計を取り付け，ケー ソンの鉛直方向と水平方向の変位を計測している.

\section{（3）相似則}

井合の提案する相似則 ${ }^{2)}$ の一部は表-3に示すとお りで，これを利用すると以下のとおりとなる。

表-3 相似則

\begin{tabular}{|c|c|}
\hline 項目 & 相似比:実物/模型 \\
\hline 長さ & $\lambda$ \\
\hline 密度 & 1 \\
\hline 時間 & $\lambda^{0.75}$ \\
\hline 変位 & $\lambda^{1.5}$ \\
\hline ひずみ & $\lambda^{0.5}$ \\
\hline 态力 & $\lambda$ \\
\hline 加速度 & 1 \\
\hline 透水係数 & $\lambda^{0.75}$ \\
\hline
\end{tabular}

模型実験では加振周期が $\mathrm{T}=0.05 \mathrm{~s}$ （振動数 $20 \mathrm{~Hz}$ ） で, 実際の地震では周期が $\mathrm{T}=1 \mathrm{~s}$ 程度の周期の摇れが 卓越していることが多いので実スケールでは周期 $\mathrm{T}=1 \mathrm{~s}$ と考えると，本模型実験の時間に関する相似比 は $\lambda^{0.75}=20$ となる.これから $\lambda \fallingdotseq 54$ 年得られる. し たがって，模型ケーソンの前面水深が $20 \mathrm{~cm}$ であるの 
で，実物スケールに直すと前面水深が約 $11 \mathrm{~m}$ の岸壁 となる。また，表-3の相似則から，実験での変位を 実物スケールに変換するには約 400 倍すれば良いこ とになり，模型実験での $1 \mathrm{~cm}$ 変位は実物スケール では $4 \mathrm{~m} の$ 変位に相当する.

透水係数については，水を用いた模型実験の透水 係数 $\mathrm{k}=1 \times 10^{-2} \mathrm{~cm} / \mathrm{s}$ は実物スケールで $\mathrm{k}=2.0 \times 10^{-1} \mathrm{~cm} / \mathrm{s}$, セルロース水溶液を用いた模型実験の透水係数 $\mathrm{k}=5$ $\times 10^{-5} \mathrm{~cm} / \mathrm{s}$ は実物スケールで $\mathrm{k}=1.0 \times 10^{-3} \mathrm{~cm} / \mathrm{s}$ となる. この透水係数に対応する土をCreagerによる土の代 表粒径および土質分類で表すと, まず模型実験のス ケールでは水の場合 $\mathrm{d}_{20} \fallingdotseq 0.2 \mathrm{~mm}$ で微粒砂, セルロー ス水溶液の場合 $\mathrm{d}_{20} \fallingdotseq 0.02 \mathrm{~mm}$ で粗砂シルトになる。実 物スケールでは水の場合 $\mathrm{d}_{20} \fallingdotseq 0.8 \mathrm{~mm}$ で粗粒砂, セル ロース水溶液の場合 $\mathrm{d}_{20} \fallingdotseq 0.08 \mathrm{~mm}$ で極微粒砂になる.

したがって, 水圧の伝播に関して今回の実験は模型 スケールの挙動では細粒分の多い地盤に対応するが, 実物スケールに換算する場合には, 細粒分を多く含 む地盤とは必ずしもいえない。このようなことから， ここでの実験は水圧伝播に関して，小さな実物，あ
るいは透水係数が2オーダー違う場合の液状化対策 範囲に関する比較実験と考えるのには問題ないと思 われるが，実物換算の場合には注意が必要である.

\section{（4）破壊震度}

図-2で示される断面について，裏埋めのせん断抵 抗角を通常の設計で用いる $\phi=30^{\circ}$ と設定すると, 震度 $\mathrm{k}_{\mathrm{h}}=0.1$ (見かけの震度が 0.2 ) で転倒安全率が $\mathrm{FS}_{\mathrm{S}}=1.1$ を下回ることとなる.この場合, 対応する地 震時崩壊角は $45^{\circ}$ で, 崩壊面が地表面に到達する位 置は,ケーソン背後 $20 \mathrm{~cm}$ の位置で図-1のA地盤のや や内側となっている. 転倒安全率が $F_{S}=1.0$ を下回る のは震度 $\mathrm{k}_{\mathrm{h}}=0.125$ (見かけの震度が 0.25 )で, この場 合崩壊角は $41^{\circ}$ となり, 崩壊面が地表面に到達する 位置はケーソン背後 $23 \mathrm{~cm}$ の位置で図-1のA地盤とB地 盤の境界位置なる。したがって, 震度 0.1 に対応す る100Gal程度の加速度が作用した場合に模型岸壁は 破壊することになる. なお，滑動安全率はFs $=1.5$ 以 上である。

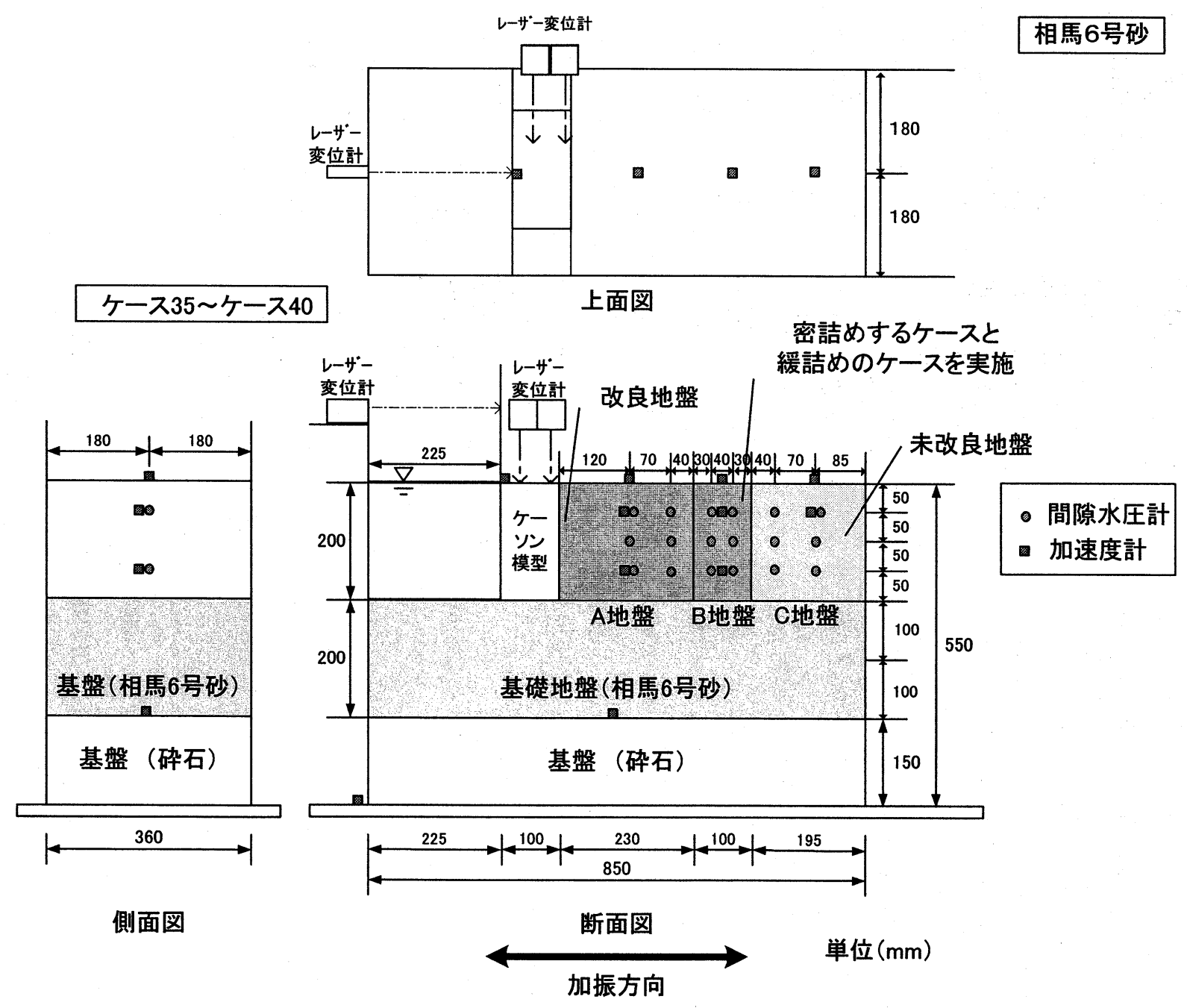

図-2 模型振動台試験の概要図 


\section{3. 振動台試験結果}

\section{(1) 加速度の時刻歴}

図-3に，入力加速度が $100 \mathrm{Gal}$ のとき加振テーブ ルおよびA地盤地表面での加速度時刻歴を示す（入 力加速度は公称值で, 振動台の台加速度とほぼ等し い值である）。図-3から加振テーブルではほぼ 100Galの振幅で規則的な加振がなされているが，A 地盤地表面では300Galを超える加速度が記録され， 波形が乱れていることがわかる。このことから，地 盤内では入力加速度が増幅されていることがわかる.

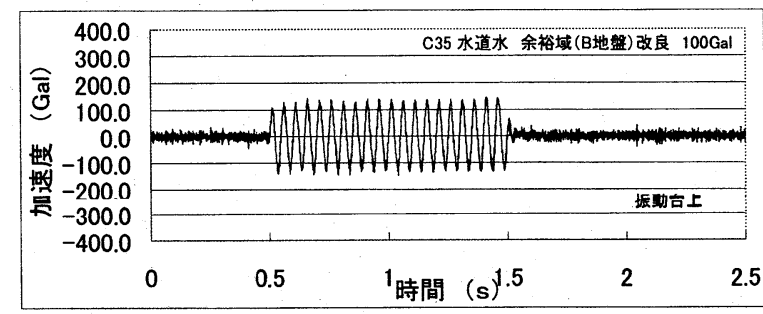

図-3(a) 加振テーブル上の加速度 (入力 $100 \mathrm{Gal}$ )

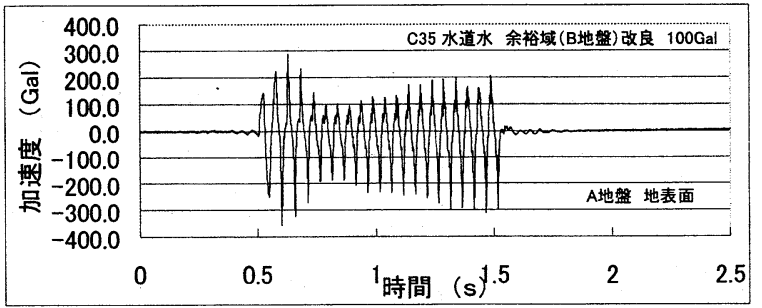

図-3 (b) A地盤地表面の加速度 (入力100Ga1)

\section{（2）加振加速度と変位の関係}

図-4に入力加速度とケーソン天端の合成変位の関 係，水平変位と鉛直変位の関係を示す。プロットの 種類は，ケース $35 \bigcirc$ ，ケース $36 \boldsymbol{\Delta}$ ，ケース 400 ,

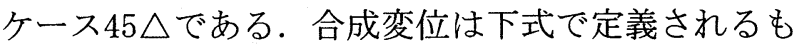
のである

$\delta_{v h}=\sqrt{\delta_{h}^{2}+\delta_{v}^{2}}$

ここに， $\delta_{\mathrm{vh}}, \delta_{\mathrm{h}}, \delta_{\mathrm{v}}$ はケーソン天端の合成変位， 水平変位，鉛直変位である．各変位は各加振段階に おいて発生した残留変位である。

図-4(a) から，入力加速度が50Galではいずれの ケースも大きな変位は発生していない，入力加速度 が100Galで0. 05〜0. 25cmの変位が発生している。こ れを実物スケールに換算すると $20 \sim 100 \mathrm{~cm}$ となり， かなり大きな変位に相当する。変位は，ケース 36 , 35，45，40の順番で小さくなっており，セルロース を用いた方が，水道水よりも小さくなっており，透 水係数の影響が見られる．特に，水道水を用いた地 盤で余裕域（B地盤）を改良したケースよりもセル ロース溶液地盤で余裕域未改良の方が小さくなって おり，透水性が低い場合に余裕域を設ける必要がな い可能性を示している。 図-4(b) から，鉛直変位よりも水平変位が卓越し ており，前章の破壊震度の検討では転倒で破壊と なっていたが実験では滑動モードが支配的である.

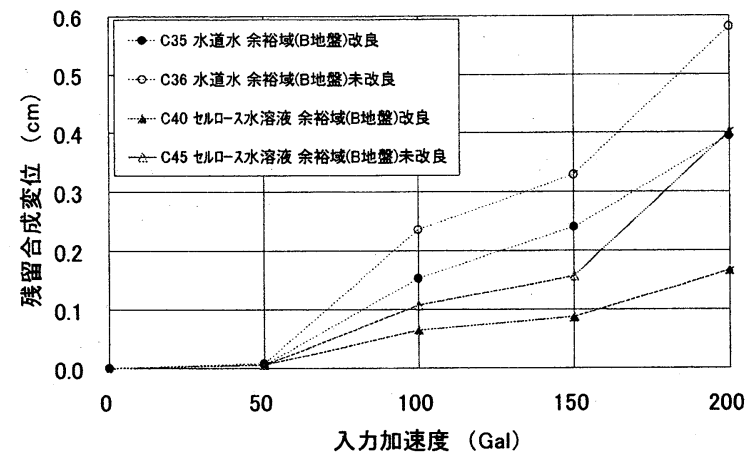

図-4(a) 入力加速度と残留合成変位の関係

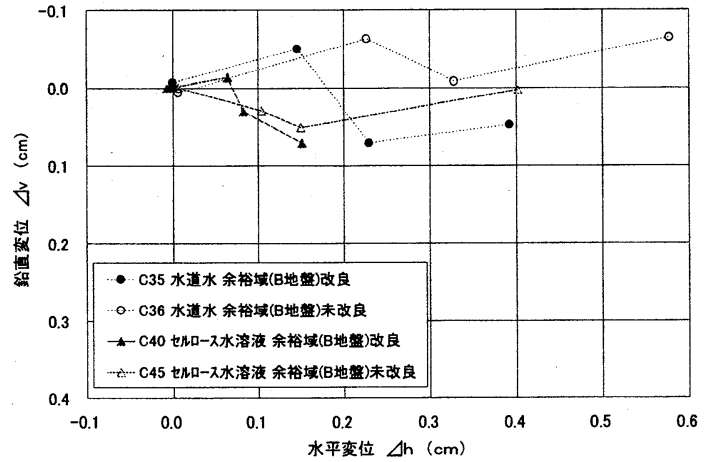

図-4(b) 水平変位と鉛直変位の関係

\section{（3）過剰間隌水圧}

図-5に入力加速度が50Gal と $100 \mathrm{Gal}$ のC地盤 (未改 良地盤)および入力加速度が $100 \mathrm{Gal}$ の地盤 (改良地

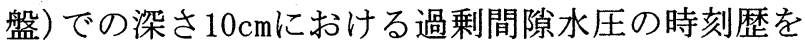

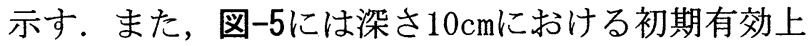
載圧 (未改良地盤 $\sigma{ }_{\mathrm{v} 0}{ }^{\prime}=0.79 \mathrm{kN} / \mathrm{m}^{2}$, 改良地盤 $\left.\sigma_{\mathrm{v} 0}{ }^{\prime}=0.92 \mathrm{kN} / \mathrm{m}^{2}\right)$ を直線で示す. 未改良地盤の場合, 入力加速度が $50 \mathrm{Gal}$ では間隙水圧は初期有効上載圧 に至っていないが，100Galでは初期有効上載圧と等 しくなっている. したがって，100Gal加振のときに 未改良地盤は液状化したといえる. 改良地盤のA地 盤の場合には $100 \mathrm{Gal}$ 加振でも過剩間隙水圧は有効上 載圧に等しくはなっておらず，液状化には至ってい ない。また，正のダイレイタンシーに起因した負圧 の発生が見られる。

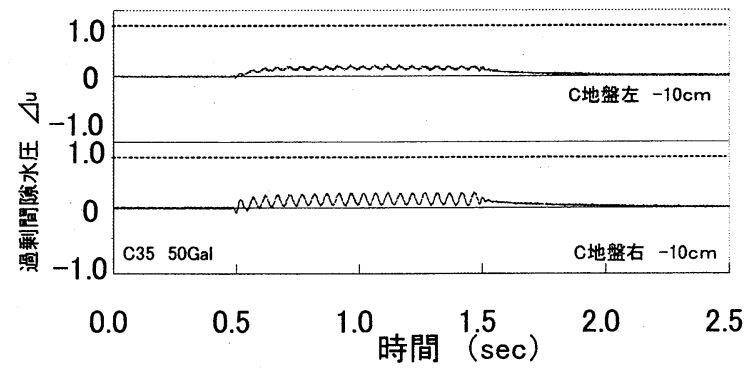

図-5 (a) 未改良地盤の間隙水圧 (50Gal) 


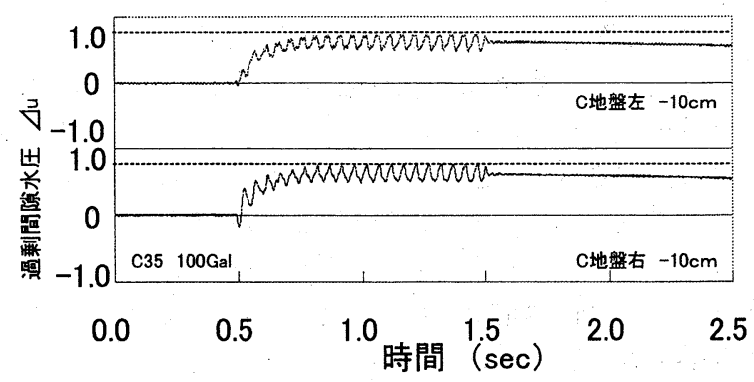

図-5(b) 未改良地盤の間隙水圧 (100Gal)

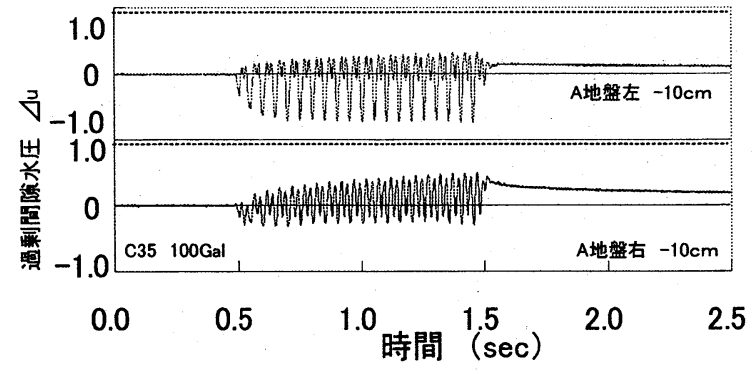

図-5（c）改良地盤の間隙水圧 (100Ga1)

\section{4. 振動台試験の考察}

前章で示したように, 入力加速度50Galでは未改 良地盤で液状化は発生せず，ケーソンにもほとんど

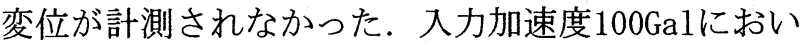
て, 未改良地盤で液状化が観察され，ケーソンにも 変位が生じた。 また, 水道水を用いた場合とセル ロース水溶液を用いた場合の変位の発生量に違いが

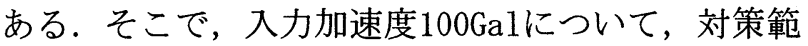
囲の効果に関する地盤の透水性の影響を考察する.

\section{（1）過㮃間隙水圧の分布}

図-6に入力加速度 $100 \mathrm{Gal}$ の, 深さ $10 \mathrm{~cm}$ におり過 剩間隙水圧の水平分布を示す. 図-6 (a) は水道水を 用いた場合で余裕域改良（B地盤改良），図-6(b) は 水道水を用いた場合で余裕域未改良, 図-6(c) はセ ルロース水溶液を用いた場合で余裕域改良, 図一 6(d) はセルロース水溶液を用いた場合で余裕域未改 良, 図-6の各図-には加振直前, 加振開始後 0.1 秒, 0.5 秒, 1.0 秒（加振停止時）, および加振停止後 1 秒での水圧が示されている.

図一から，余裕域を改良した場合の方が，水道水, セルロース溶液のいずれにおいても改良地盤左側

（A地盤）における過剩間隙水圧は小さくなってい ることがわかる. また, 間隙が水道水の場合には加 振終了後の間隙水圧の消散が速く, セルロース水溶 液の場合には消散が遅いことがわかる。したがって， 水圧の伝播はセルロース水溶液の方が起きにくい.

加振中については，セルロース溶液の方の圧力が 上がりにくい傾向は認められるが，やや不明瞭であ る。また, 透水性の違いによって, 余裕域改良効果 の違いが間隙水圧の分布形状に明確に表れていると はいえない，加振中の 2 次液状化については，余裕
域を設けた場合にはA地盤で発生していないのは明 らかであるが，余裕域を設けない場合についてはセ ルロースおよび水道水のいずれのケースも水圧がか なり上がっており，2次液状化に近い状態である.

次に，ケーソン変位に最も影響を与えると考えら れるA地盤の間隙水圧の時刻歴を次節で考察する.

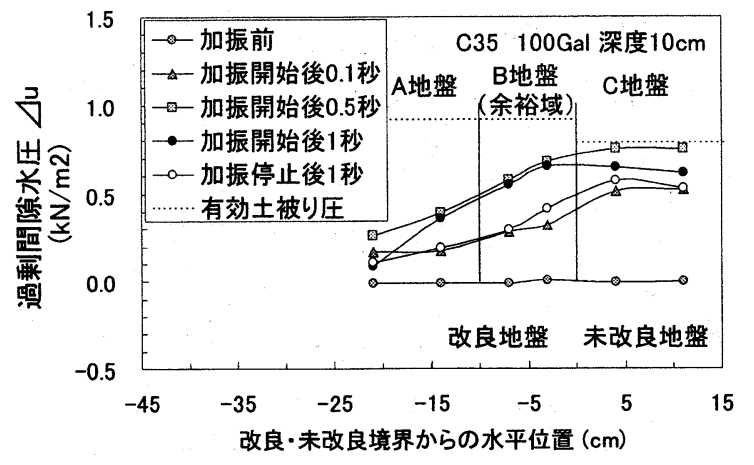

図-6（a）間隙水圧 (余裕域改良：水)

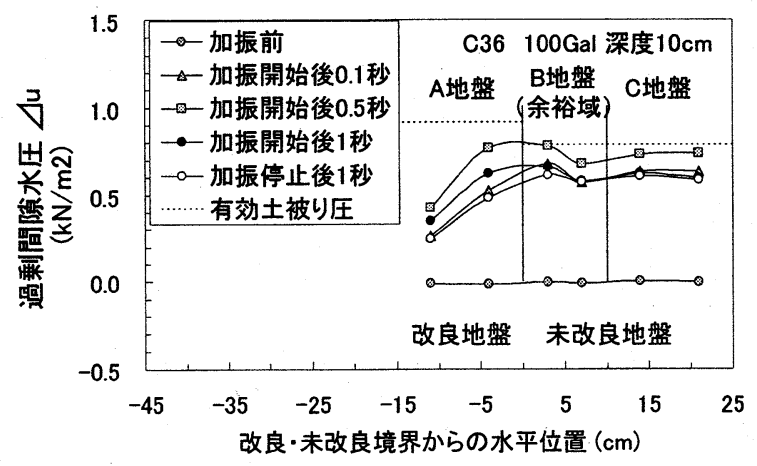

図-6 (b) 間隙水圧分 (余裕域未改良: 水)

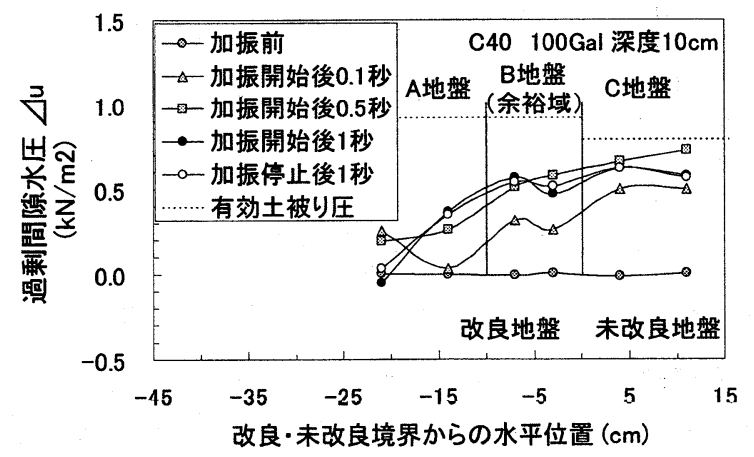

図-6(c) 間隙水圧(余裕域改良:セルロース)

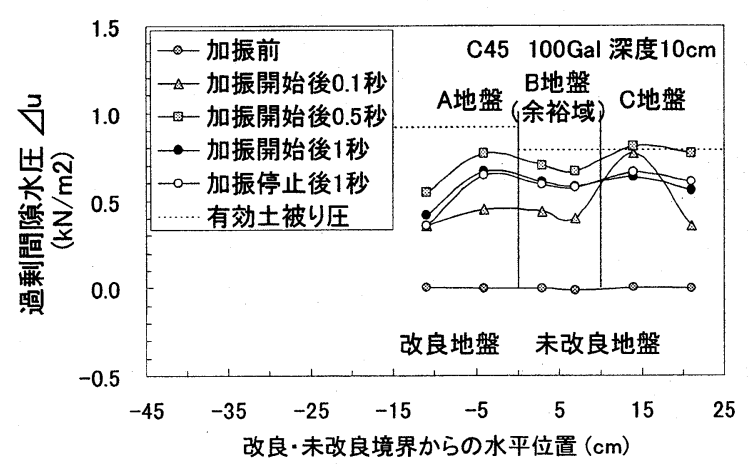

図-6 (d) 間隙水圧 (余裕域未改良 : セルロース) 


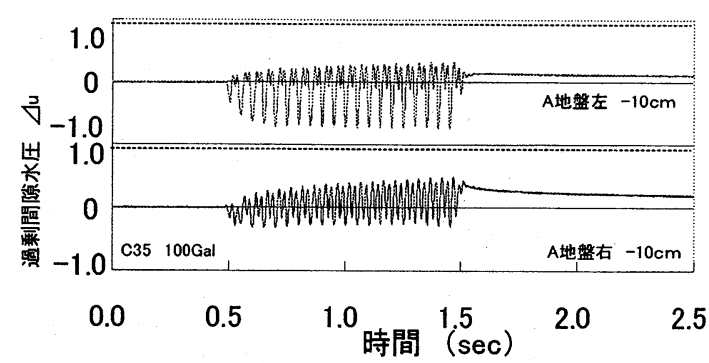

図-7（a）間隙水圧時刻歴(余裕域改良：水)

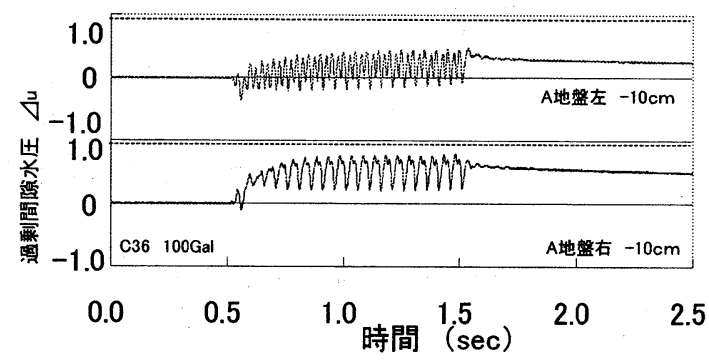

図-7(b) 間隙水圧時刻歴(余裕域未改良:水)

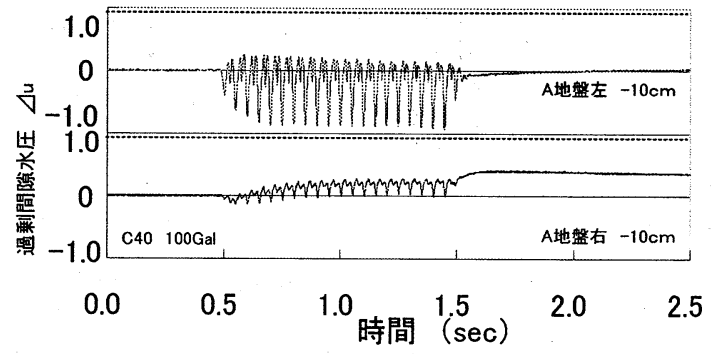

図-7(c) 間隙水圧時刻歴(余裕域改良:セルロース)

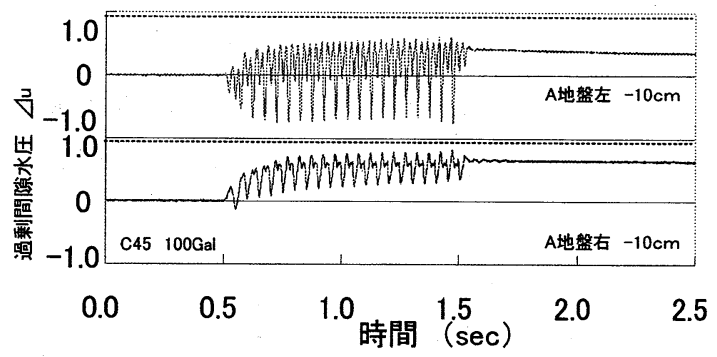

図-7(d) 間隙水圧時刻歴(余裕域未改良:セルロース)

\section{（2）過剩間隙水圧の時刻歴}

図-7に入力加速度 $100 \mathrm{Ga}$ の場合の, A地盤の深さ $10 \mathrm{~cm}$ における右側, 左側の間隙水圧の時刻歷を示す. 図-7（a）は水道水を用いた場合で余裕域（B地盤）改 良, 図-7(b) は水道水を用いた場合で余裕域未改良, 図-7(c) はセルロース水溶液を用いた場合で余裕域 改良, 図-7(d) はセルロース水溶液を用いた場合で 余裕域未改良である.

図-7 (c) と図-7 (a) を比較すると, 特にA地盤右側 の時刻歴に違いがあり，図-7(c)の方が間隙水圧の 発生量が小さい。このことは，図-4(a)で余裕域が 改良の場合においてセルロース溶液の方が小さな ケーソン変位であったことに対応する。

図-7 (b) と図-7(d)を比較すると，A地盤右側では 時刻歴に大きな違いが見られない。しかし，A地盤 左側では図-7(d)において負圧が発生しているが, 図-7(b)では発生していない。負圧は外力に対する 抵抗に寄与し，図-4(a) で余裕域未改良の場合にセ ルロースの方が小さな変位であったことに対応する.

図-7 (a) と図-7 (d) を比較すると大きな違いは見ら れず, 過剩間隙水圧の発生量は図-7(d)の方が大き くなっている。このことは, 図-4(a)において余裕 域改良の水道水地盤よりも, 余裕域未改良のセル ロース溶液地盤の方が小さなケーソン変位であった ことを説明できない。したがって，間隙水圧挙動だ けから変位の違いをすべて説明することはできない。

\section{（3）地盤の透水性の影響および余裕域}

加振中の改良地盤における間隙水圧の時刻歷につ いては，水道水よりもセルロース溶液を用いた方が 間隙水圧の発生量が小さく，また負圧が発生しやす い傾向にあった。これらを透水性と関連付けて説明 すると，セルロース溶液を用いた方が小さな透水係 数であるために非排水条件が守られやすかったから であると説明できる，すなわち，周囲から過剩間隙 水圧が伝播しにくく，ダイレイタンシーに起因した 負圧も発生しやすかったということになる。このよ うなことから，透水性の低いセルロース溶液を用い た方が小さなケーソン変位になったと説明できる.

余裕域改良の効果と透水性に関しては，透水性の 低いセルロース溶液地盤では余裕域を改良しなくて も，水道水地盤で余裕域改良した地盤より小さな ケーソン変位となった。この比較から, 透水性の低 い場合には余裕域を改良しなくても良いということ になる。しかし, 間隙水圧の挙動からは (2) 節で述 べたような矛盾が見られ，余裕域改良の必要性につ いて水圧伝播の観点からは明確に説明できない.

\section{5. おわりに}

ケーソン岸壁裏埋めの液状化対策として締固めを 行う場合，対策範囲の設定について細粒分を多く含 む地盤と含まない地盤で透水性の違いから余裕域改 良の必要性に違いがあると考え, 振動台試験で違い を調べた. その結果, 透水性の違いが改良後の耐震 性に反映されることがわかった，また，透水性が低 い地盤では余裕域が必要ないという実験結果であっ たが，その明確な理由および定量的評価を得ること ができなかった. 今後は, 数值解析なども利用して この点を明確にし, 余裕域と透水性, 細粒分含有率 の関係について定量的な結論を出す必要がある。そ のために, 排水を考慮した液状化解析のできる2次 元FEMを開発し, 害験結果の解析を行う予定である.

\section{参考文献}

1) 井合進, 小泉勝彦, 倉田栄一: 液状化対策としての地 盤の締固め笧囲に関する基礎的検討, 港湾技研資料, No.590,pp.1〜66, 1987.

2) 井合進 : 1g場での地盤-構造物-流体系の模型実験の相似 則，港研報告，第27巻，第3号，pp.3 24, 1988. 